myia shows that in each case there are rudimentary lobes homologous with our "terminal lobes" at or near the base of the acicula. It is only a step from the conditions described in the Lasioptera named abore, with its well developed terminal lobes and the apical acicula arising just below, to follow the reduction and migration of these organs cephalad as in Monarthropalpus and Sackenomyia, and to proceed from this to what we find in Asphondylia with its highly developed terminal lobes apparently at the base of the ovipositor. The relationship obtaining in the last named form is due simply to the mechanical necessity of having at the apex of the abdomen a sufficient length of invaginating tissue to permit the withdrawal of the extremely long acicula into the body of the female. Obviously, under these conditions there must be either reduction to practical extinction or migration, and in the case of Asphondylia the latter prevailed and was accompanied by an increase in size of the terminal lobes and their modification to form the peculiar dorsal pouch.

\title{
TWO NEW SPECIES OF HOLCASPIS FROM MEXICO.
}

\section{By William Beutenmuller.}

\section{American Museum of Natural History, New York City.}

Holcaspis weldi, sp. nov. (Plate 12, fig. 2).

Female. Head dusky yellowish brown, finely and evenly rugose, slightly pubescent. Antennæ dull brown, 14-jointed, rather stout, third joint long and slender, second subcylindrical, fourth joint shorter than the third and thick at the end, following joints shorter and sub-equal. Thorax dull yellowish brown, finely but distinctly punctate and slightly hairy. Parapsidal grooves distinct, and almost reaching the collar. Median groove continuous and broadest at the scutellum. Anterior parallel lines scarcely evident. Lateral grooves fine and not distinct. Pleuræ finely rugose. Scutellum dull yellowish brown, evenly rugose, with a linear depression along the middle and a groove-like depression across the base. Abdomen dark brown, paler dorsally, finely punctate and hairy along the sides. Legs dull yellowish brown, middle and hind femora darker, femora rather stout. Last tarsal joint and claws large and stout. Wings dusky hyaline, somewhat clouded, veins stout and brown. Radial area open. Areolet large. Cubitus almost reaching the first cross-veins. Length 3-4 $\mathrm{mm}$.

Galt. In clusters on the terminal twigs and leaves of Quercus reticulata.

Monothalamous. Globular, thin-shelled, yellowish and tinged various shades of pink and red, covered with a dense rusty brown, pubescence, which may be rubbed off with the fingers. Inside there is a rounded kernel held in position by radiating 
fibers which are covered with a moss-like substance. The inner side of the shell is densely covered with a rusty brown moss-like substance. Diameter $20-40 \mathrm{~mm}$.

Habitat: Mexico.

The galls were purchased by Mr. Lewis H. Weld from a woman at a fruit stand on the street in the Mexico City and the specimens evidently came from the nearby mountains. The galls were bought September 12th, 1910 and the adults emerged between October and and 9th. The oak was kindly identified for me by Dr. N. L. Britton.

\section{Holcaspis mexicana, sp. nov. (Plate 12, fig. 3.)}

Female. Head yellowish brown, rugoso-punctate and covered with pale hairs. Antennæ slender, filiform, the terminal joints scarcely thicker than the basal joints, 14-jointed, first joint stout, second very short and sub-globular, third to sixth long and slender, third the longest, seventh to thirteenth gradually becoming shorter, terminal joint longer than the preceding, all yellowish-brown. Thorax finely and, densely punctate, and covered with short decumbent dull yellowish hairs; anterior parallel lines and space between black, as are also the lateral grooves. Parapsidal grooves extending forward to the middle of the thorax. Anterior parallel lines, sharply defined, smooth and almost reaching the middle of the thorax. Lateral grooves long, smooth and sharply defined. Scutellum rugose, no foveæ. Pleuræ punctate, hairy. Abdomen smooth, shining with short hairs at the base. Reddish-brown, posterior end of second and third segment blackish brown dorsally. Legs dark yellowish-brown and hairy. Wings yellowish hyaline, veins dark brown and stout. Radial veins almost touching the costal marging. Areolet distinct. Cubitus terminating some distance from the first cross-vein. Length, $4 \mathrm{~mm}$.

GALL. In a compact mass around the terminal twig of a species of oak. More or less rounded with the sides usually flattenerl and pressed out of shape. Smooth, somewhat shining, clay brown more or less tinged with red. Hard and woody with a single rounded larval chamber near the base of the gall and firmly imbedded in the hard inner substance. The individual galls measure from $8-18 \mathrm{~mm}$. in diameter and the entire mass $30 \mathrm{~mm}$. in length and $25 \mathrm{~mm}$., in width.

\section{Habitat: Guadalajara, Mexico. (D. L. Crawford.)}

The specimen I received from Prof. C. F. Baker.

Explanation of Plate 12.

Fig. 1. Holcaspis mexicana sp. nov.

2. Holcaspis mexicana sp. nov. Inside view.

3. Holcaspis weldi sp. nov. 

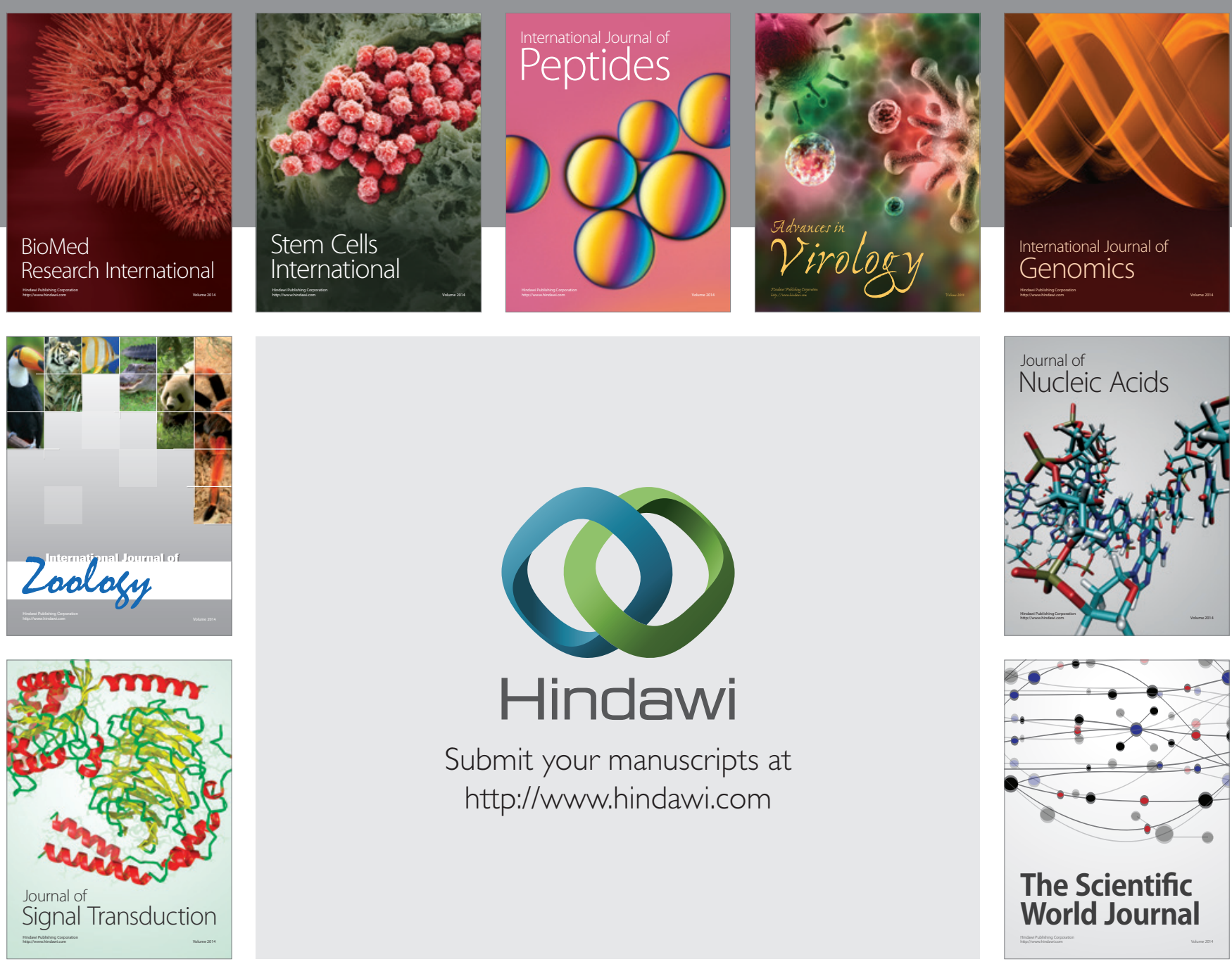

Submit your manuscripts at

http://www.hindawi.com
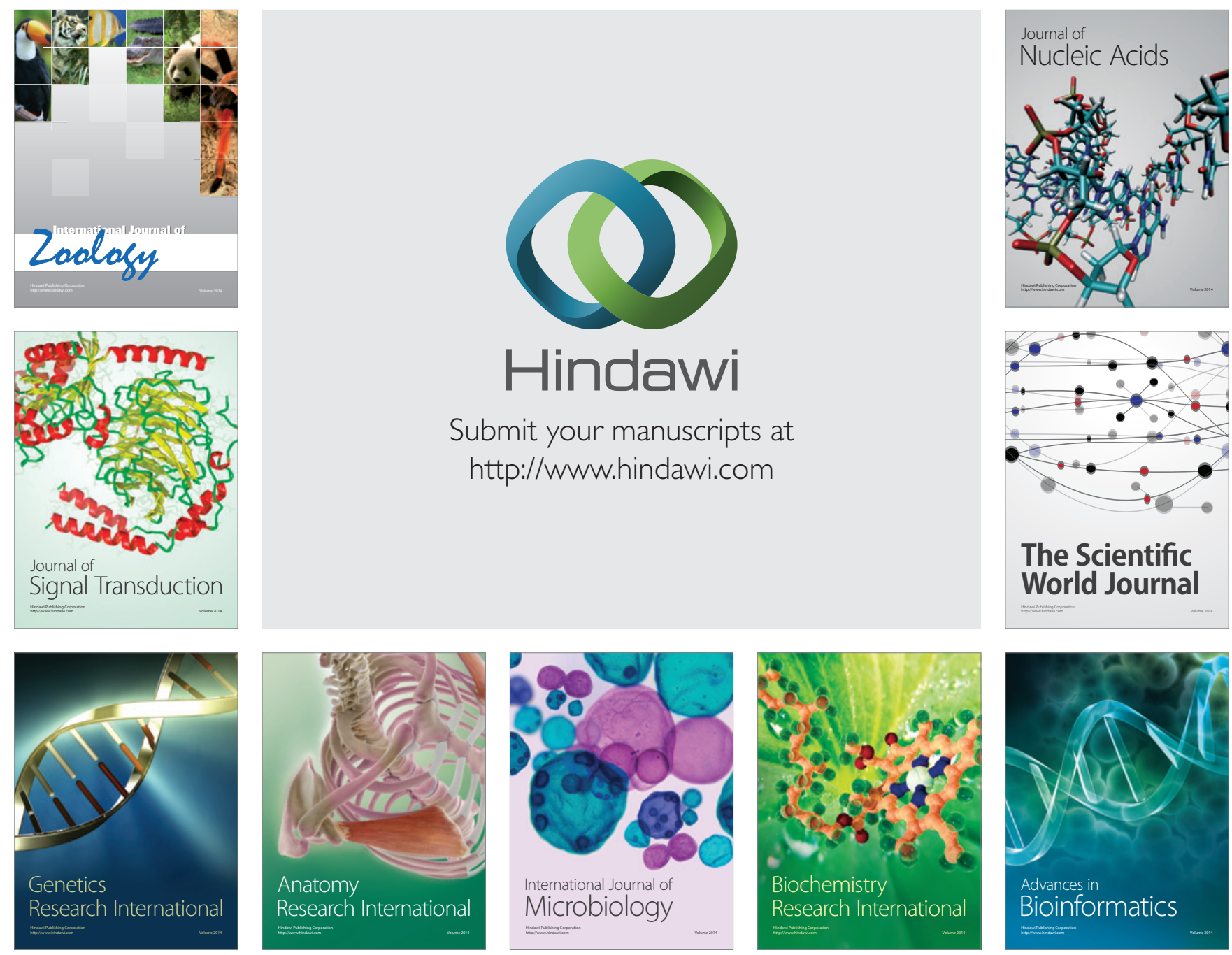

The Scientific World Journal
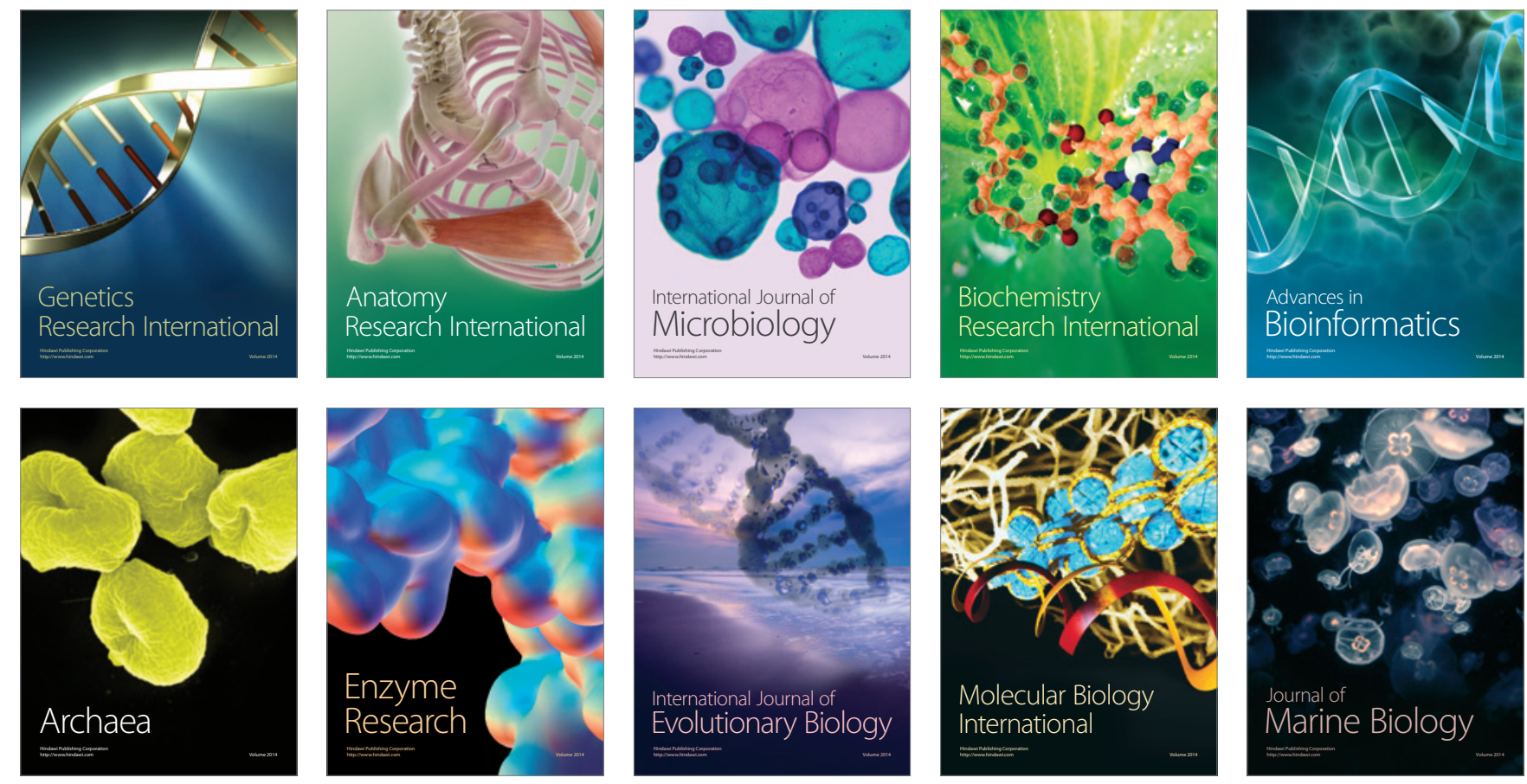